\title{
Heeding the Call for Social Justice: How a CPED Ed.D. Program Illuminates the Instructional Intersection Between COVID-19 and the Black Lives Matter Movement
}

\author{
Nancy Nasr \\ Granada Hills Charter High School \\ nnasr@ghctk12.com
}

\begin{abstract}
The intersection of the COVID-19 pandemic and the BLM movement led to a historic moment for American society. Illness, death, and civil unrest provided a shared historical experience for all Americans, and provided an opportunity for educators to capitalize on the multitude of teachable moments these historical events provided. For educators, like myself, who were the product of CPED Ed.D. programs that emphasized social justice in education, the historical events of COVID-19 and the BLM movement were immediately recognized as an opportunity to bring social justice to the forefront in the online classroom. The purpose of this manuscript is to reflect on the impact that my CPED Ed.D. experience had on my awareness of social justice in education and how this awareness translates to online learning opportunities in light of the COVID-19 pandemic to provide students with experiences that emphasize the need to understand and overcome social injustices, through science.
\end{abstract}

\section{KEYWORDS}

social justice, science, online learning, Black Lives Matter, COVID-19

\section{A RESURGENCE OF THE BLACK LIVES MATTER MOVEMENT}

Breonna Taylor, Ahmaud Arbery, George Floyd. All of these names belonged to Black Americans murdered because of an ugly underbelly of American culture; that of systemic racism against Black citizens. In the weeks following the murders of Taylor, Arbery, and Floyd, thousands of people in the United States, and globally, took to the streets in acts of protest to demand awareness for systemic racism and to call for an end to oppressive policing measures that disproportionately impact Black people. Though not new, the civil unrest that emerged as a result of the murders of Taylor, Arbery, and Floyd, brought to light a rebirth of the Black Lives Matter (BLM) movement. As the primary goal of the BLM movement is to bring awareness to "the daily violence and systemic oppression Black people experience" (Castillo-Montoya et al., 2019, p. 1126), it becomes imperative for the BLM movement to gain traction in schools as a means to educate society's youth about the plight of Black people in contemporary America. Doing so honors the need for greater social justice awareness in education, particularly as a society's ability to reconstruct itself stems from the vitality and awareness of its youth (Schiro, 2013).

\section{THE COVID-19 PANDEMIC AND THE CALLS FOR SOCIAL JUSTICE}

The renewed uprising of the BLM movement occurred at a time when safer-at-home orders were issued across the country in response to the COVID-19 pandemic. Though government officials across the country recommended citizens limit the spread of coronavirus by remaining at home, the social call for action was too great for those whose lives and identities were impacted by the murders of Breonna, Ahmaud, and George. As an educator, I knew that the unprecedented events of COVID-19 coupled with the historic social protests of BLM could not, and should not, be isolated from each other, and I also knew that the COVID-19 pandemic meant instruction would continue to be delivered online for most educators. With this in mind, I began to wonder, how could I ensure that my online science curriculum honored the central tenets of the BLM movement in the context of COVID-19? Before describing the ways in which I decided to address the intersection of COVID-19 and the BLM movement in my online science curriculum, a reflection on my doctoral experience is important.
New articles in this journal are licensed under a Creative Commons Attribution 4.0 United States License.

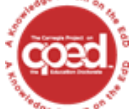

This journal is supported by the Carnegie Project on the Education Doctorate: A Knowledge Forum on the EdD (CPED) cpedinitiative.org 


\section{SOCIAL JUSTICE AS A PROMINENT THEME IN CPED PROGRAMS}

I was fortunate to realize that I would be returning to my high school science teaching position armed with a freshly minted Doctor of Education (Ed.D.) degree from a university that is a member of the Carnegie Project on the Education Doctorate (CPED). As a member of the CPED consortium, the notion of social justice, and how a CPED Ed.D. program could better prepare educators to tackle social justice issues was frequently emphasized. From social justice issues such as under-representation of minorities in certain academic disciplines, to organized "policing" of schools, there was no shortage of opportunities to use my experiences in a CPED Ed.D. program to design classroom learning sequences that empowered my students to view science as a vehicle for social change; in fact, the reignition of the BLM movement provided one such opportunity. Because of my experiences in a CPED Ed.D. program I noticed a marked shift in my own curricular ideology. Early in my career as an educator, I staunchly aligned with the scholar academic curricular ideology (Schiro, 2013) wherein instruction was heavily content-based and relied on traditional modes of transmission; however, with exposure to alternative curricular ideologies through my CPED Ed.D. program I began to find myself transitioning toward the social reconstructionist ideology (Schiro, 2013), wherein I viewed teaching as an opportunity to raise student awareness to issues of social injustice plaguing marginalized communities. With historical events such as COVID-19 and the BLM movement, I began to reflect on the ways that education could be used as a vehicle to reconstruct society. Indeed, my identity development as an educator was facilitated through the emphasis of social justice throughout my CPED Ed.D. program.

\section{CPED PROGRAMS DRAW AWARENESS TO RACE IN THE SCHOOLING SYSTEM}

In addition to emphasizing the link between my CPED Ed.D. program and my resulting understanding of the social justice issues beleaguering society, my participation in a CPED Ed.D. program also provided me with ample opportunities to critically examine the role of race in the American schooling system. Courses centered around topics such as diversity and race in curriculum structures promoted an even deeper awareness of the injustices experienced by students of color. Prior to this coursework, I was unaware of the ways in which common disciplinary tactics used by schools disproportionately impact students of color, or how the notion of color-blindness is an often-misguided attempt to appear as a "non-racist", or how many curricular approaches reflect an assimilationist position on race in the classroom. The acquisition of this knowledge through my CPED Ed.D. program further strengthened my desire to model anti-racist teaching in my classroom. I knew that my emergent understanding of anti-racism in the classroom could be used to further refine my own classroom-level curriculum in a way that ensured both cultural responsiveness and a respectful acknowledgement of the contributions and differences of a wide array of races represented in my diverse classroom, as well as a commitment to action against racism. In this way, my CPED Ed.D. program aligned strongly to the vision of the CPED wherein I developed into a "well-equipped scholarly [practitioner to] provide stewardship...and meet the educational challenges of the $21^{\text {st }}$ century" (The Carnegie Project on the Education Doctorate, 2020). Indeed, careful attention to diversity, race, and overcoming the social injustices of marginalized communities is a key challenge of the $21^{\text {st }}$ century that socially conscious educators have a moral duty to address in their classrooms.

\section{DISSERTATION IN PRACTICE EXPERIENCES DEVELOP UNDERSTANDING OF SOCIAL JUSTICE}

I knew that social justice was a key component of my doctoral program, however, with a limited understanding of social injustices in the education system at the time, my ideas about social justice in the science classroom were only two-dimensional, at best. It was not until I started working on my dissertation in practice (DiP) that I began to take a deeper dive into the notion of social justice, and specifically how true social justice in education cannot dilute the experiences of the marginalized. In the early stages of dissertation writing, I thought that honoring social justice simply meant ensuring that I delivered lessons aligned with culturally responsive pedagogy (CRP). Little did I know that CRP is only one minor facet of the social justice movement in education, and that truly tackling issues of social injustice meant delivering lessons that required a closer look at systemic racism. In fact, it was not until I started writing my DiP that I realized my important role as a social justice advocate particularly as my student population is highly diverse, constituting approximately $50 \%$ Latinx and African American students. As my DiP took a close look at the Next Generation Science Standards (NGSS), it was only natural to assume that social justice meant ensuring that the unique and diverse backgrounds of students were used as an asset to solve scientific problems. Though this is undoubtedly one important facet of social justice in science, my deeper understanding of the NGSS, through the development of my DiP, led me to explore disciplinary core ideas rooted in phenomena that embodied social injustice. For example, I started developing greater proficiency at designing lesson sequences that tackled phenomena such as how air pollution disproportionately impacts people of color or how the Flint water crisis still plagues predominantly Black communities. These phenomena were used not only to address the disciplinary core objectives of my course through the NGSS, but were also used to address an even bigger social problem; that of environmental racism.

\section{COVID-19 AND THE CALL FOR REMOTE LESSONS CENTERED ON SOCIAL JUSTICE}

As my doctoral experience at a CPED consortium institution helped develop my deeper understanding of social justice, I knew that the impact of the COVID-19 pandemic meant that delivering science lessons rooted in social justice must occur remotely. As our school district continues to institute a safer-at-home order I knew to expect another semester of online teaching, however, I also knew that I could not let the events that inspired the reignition of the BLM movement go unaddressed in my online science classroom. In fact, while some may view the requirement for online teaching as a significant hindrance, I view it as a welcome means to address issues of social justice. As the "internet can now deliver text, voice, audio, and video messages that give students the ability to see and hear social events occurring elsewhere" (Schiro, 2013, p. 186), the use of technology in the online classroom becomes a significant asset to allow students an opportunity to connect authentically to social injustices. As described above, my doctoral program experience effectively helped me understand that social justice 
"requires not only the recognition of social group differences, but also an understanding of how social differences... are connected to social group inequality" (Adams, 2018, p. 2). However, with this understanding in mind, it was now up to me to ensure that I was meeting the goals of social justice education by providing my students with learning opportunities that helped them develop the "critical analytical tools necessary to understand the structural features of oppression and their own socialization within oppressive systems" (Bell, 2016, p. 4), even in online formats.

\section{JUSTICE-ORIENTED AND RACIALLY LIBERATORY SCIENCE PEDAGOGIES}

Experienced with searches for scholarly literature, I began researching the ways that social justice teaching could be delivered to students in online formats, paying particular attention to addressing the experiences of pervasive Black racism. From my research, I discovered two important pedagogical approaches; justice-oriented science pedagogy (Davis \& Schaeffer, 2019) and racially liberatory pedagogy (Castillo-Montoya, Abreu, \& Abad, 2019), as well as Earth Force's community action and problemsolving process (https://www.earthforceresources.org, 2020). These approaches highlighted the ways in which teaching could be used to bring awareness to the plight of racial groups impacted by systemic racism, as well as empower students, particularly those students belonging to marginalized communities, to enact social change. While Davis and Schaeffer (2019) provided a working definition of justice-oriented science pedagogy, Castillo-Montoya et al. (2019) provided a framework for delivering instruction situated in racially liberatory pedagogy. Though these two pedagogical approaches provided a starting point, I had to remember that the consequences of the COVID-19 pandemic meant that these pedagogical strategies had to be refined for the online classroom. In addition, the online classroom had to also support the ability for students to envision and propose ways to enact change in their communities.

\section{IMPLEMENTING JUSTICE-ORIENTED AND RACIALLY LIBERATORY SCIENCE PEDAGOGIES ONLINE}

Working through my DiP I became deeply familiar with the NGSS and how to implement it in my classroom. Providing students ample opportunities to plan and conduct their own investigations, collect and analyze data, and engage in argument from evidence became cornerstones of my science curriculum. As instruction moved to online formats due to the COVID-19 pandemic, I had to provide alternative online access to the fundamental principles of the NGSS and as a result, students had to be provided with data sets that allowed them to continue data analysis and engage in argument from evidence, without actually conducting the investigations themselves. Providing students with remote experiences with the process of science learning not only aligns with the vision of the NGSS but also provides a platform for science instruction that encourages students to explore social justice phenomena by linking the process of science learning to larger societal issues. Inquiry experiences that were once conducted in traditional classroom settings could be moved to online platforms by sharing online access to data sets, allowing students to engage in the collaborative process of developing scientific arguments through online "breakout rooms", and allowing students to propose action plans aimed at improving their communities through remote presentations.

\section{INTERSECTING BLM AND COVID-19 THROUGH ONLINE INSTRUCTION TO PROMOTE SOCIAL JUSTICE}

Linking the BLM movement to the COVID-19 pandemic provides an opportunity to engage science learners in online NGSS instruction while also investigating a prominent social justice issue: coronavirus spreading more rapidly in the predominantly Black city of Flint, Michigan. Engaging online science students with short video clips that detail how handwashing is a critical step in slowing down the spread of coronavirus, and how handwashing became a difficult endeavor in Flint sets the stage for student awareness of social injustice. In fact, engaging students in videos that "hook" them into the social injustices plaguing Flint sets the stage for deep and intense discussions aimed at bringing awareness and a desire for social reconstruction. As discussion is a cornerstone of teaching anchored in social justice (Schiro, 2013) it is also a pedagogical strategy that can be readily realized in online formats through commonly used platforms such as Google Meets and Zoom.

Capitalizing on the awareness that intense discussion brings, students can then be posed the following guiding question: which population group is most affected by the spread of coronavirus in Genesee county? Genesee county was chosen as the geographical location of analysis as this is the location of Flint, Michigan. Posing this guiding question sets the stage for additional virtual discussions and allows students to voice additional authentic concerns and opinions centered on social injustice. Students can then use these discussion points to frame their analysis of statistical data showing that Black populations in Genesee county, and specifically those in Flint, are the most impacted by the coronavirus. Using statistical data analysis as a remote teaching strategy allows students to experience and analyze the social injustices of Flint and might embolden students to think about how these social injustices might be mitigated. Furthermore, allowing diverse students an opportunity to analyze data that is relevant and meaningful to the current society provides them with a deep connection to science learning. This relevance and meaning is fostered through student feelings about "what is socially just or unjust, good or bad, fair or unfair, right or wrong" (Schiro, 2013, p. 186).

Concluding that Black populations in Flint are most impacted by the coronavirus fosters an opportunity for another virtual discussion of why. To begin the discussion, students might first be asked if they have heard of the term environmental racism. Additionally, students might be asked to reflect on other instances of environmental racism, prompting reflections related to air pollution or the emergency response to hurricane Katrina. Bringing awareness to environmental racism honors the central purpose of social justice education as a means to identify areas of society that are unjust and improve those areas for a better future society. Furthermore, after linking the social injustices of Flint to environmental racism students can begin to think about what can be done to overcome this social justice issue and might serve as a summative assessment that can be readily researched and delivered online. Providing students with an opportunity to develop action plans to overcome social injustices, empowers them and aligns with Gay's (2002) assertion that culturally responsive teaching ought to be transformative for students. 


\section{CONCLUSION}

The intersection of the COVID-19 pandemic and the BLM movement led to a historic moment for American society. Illness, death, and civil unrest not only provided a shared historical experience for all Americans, but also provided an opportunity for educators to capitalize on the multitude of teachable moments these historical events provided. For educators, such as myself, who were the product of CPED Ed.D. programs that emphasized social justice in education, the historical events of COVID-19 and the BLM movement were immediately recognized as an opportunity to bring social justice to the forefront in the online classroom. The COVID-19 pandemic resulted in teachers, like myself, finding themselves in the position of redesigning their face-to-face lessons to accommodate online platforms. This curricular redesign added an additional layer of complexity to the already complex task of planning lessons that addressed not only the disciplinary content of courses, but did so in a way that fostered continued critical thinking of students. As a science educator tasked with developing online science lessons, I had to also develop lessons that honored the three-dimensionality of science learning without ignoring the need to bring awareness to issues of social justice. Indeed, the COVID-19 pandemic coupled with the reignition of the BLM movement provided an opportunity for science educators to use their online classrooms to bring awareness to the science linking these two phenomena. Not only do these two phenomena provide an opportunity for students to engage with the process of science learning, but they also provide an opportunity for online students to address a universal truth; that Black Lives Matter.

\section{REFERENCES}

Adams, M. (2018). Core concepts for social justice education. In M. Adams, W.J. Bumenfeld, D.C.J. Catalano, K, DeJong, H.W. Hackman, L.E. Hopkins, B.J. Love, M.L. Peters, D. Shlasko, \& X. Zuniga (Eds.), Readings for diversity and social justice (pp. 1-6). Routledge.

Bell, L. (2016). Theoretical foundations for social justice education. In M. Adams, W.J., Bell, L., Goodman, D. J., \& Joshi, K. Y. (Eds.), Teaching for diversity and social justice (pp. 3-27). Routledge.

Castillo-Montoya, M., Abreu, J., \& Abad, A. (2019). Racially liberatory pedagogy: A black lives matter approach to education. International Journal of Qualitative Studies in Education, 32(9), 1125-1145.

Davis, N. R., \& Schaeffer, J. (2019). Troubling troubled waters in elementary science education: Politics, ethics \& black children's conceptions of water [justice] in the era of flint. Cognition and Instruction, 37(3), 367389.

Earth Force Resources. (n.d.). Earth force process. https://earthforceresources.org/efprocess/

Gay, G. (2002). Preparing for culturally responsive teaching. Journal of Teacher Education, 53(2), 106-116.

Schiro, M.S. (2013). Curriculum theory: Conflicting visions and enduring concerns. SAGE.

The Carnegie Project on the Education Doctorate. (2020). Our vision and mission. Retrieved June 26, 2020 from https://www.cpedinitiative.org/vision-mission 